\title{
4-ニトロピリジンの塩酸-2-プロパノール溶液の 酸秦雾囲気下における光化学反応
}

\author{
(1972 年 4 月 1 日受 理)
}

\author{
橋 本 静 信・加 納 航 治・高田 郁 夫*
}

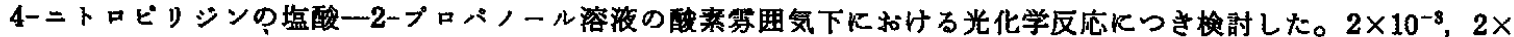

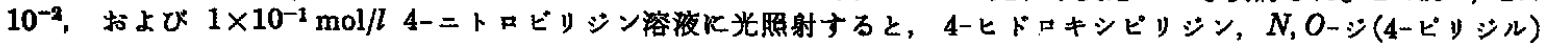

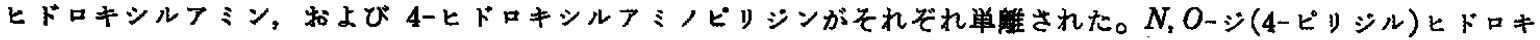
シルアミンは, 光化学的に生成した 4-ヒドロキシビョジと 4-ヒドロキシルアミノピリシンとが暗黑下で縮合する ことにより生成するすのと思われる。1,3-ペンタシェンを用いた消光実験の結果扰よび 4-ニトロピりシン共役酸の 系間交羑収率の值は，4ーヒドロキシピリシンヘの光反応が三重項状態から進行するすのであることを示唆した。
\end{abstract}

\section{1 舶言}

ニトロベンゼンや一置換ニトロベンゼン類は, テトラヒドロフ ラン,トリエチルアミン, ジエチルアミン,トリーnーブチルスタ ナン、エタノール，あるいは 2-プロパノール（以下 IPA と略記 する）といった水素供与体中で光照射されると，その三重項状態 から水素引き抜き反応が進行し，これらの光化学還元は，酸素分 子により消光されることが知られている1) 10)。同様に 4-ニト口 ピリジン 1-オキシドすエタノール中，窒索雾囲気下に光照射さ れると，還元されて定量的収率で 4-ヒドロキシルアミノピリジ ン 1-オキシドを与える(11)。 4-ニトロピリジン 1-オキシドの光 還元反応は，その最低三重項状態から進行するといらことが， Stern-Volmer 関係式を用いた実験から明らかにされている ${ }^{13)} 。$

* 同志社大学工学部工業化学科, 京都市上京区烏丸今出川

1) R. L. Ward, J.Chem. Phys., 38, 2588(1963).

2) E. G. Janzen, J. L. Gerlock, J. Amer. Chem. Soc., 91. 3108(1969).

3) C. Chachaty, A. Forchioni, Tetrahedron Lett., 1968, 307.

4) R. B. Sleight, L. H. Sutcliffe, Trans. Faraday Soc., 67, 2195(1971).

5) J.A. Barltrop, N. J. Bunce, J. Chem. Soc., (C), 1968 , 1467.

6) W. Trotter, A. C. Testa, J. Amer. Chem. Soc., 90, 7044 (1968).

7) R. Hurley, A C. Testa, ibid., 88, 4330(1966).

8) R. A. Finnegan, D. Knutson, ibid., 90, 1670(1968).

9) S. Hashimoto, J. Sunamoto, H. Fujii, K. Kano, Bull. Chem. Soc. Jap., 41, 1249(1968).

10) S. Hashimoto, K. Kano, Tetrahedron Lett., 1970, 3509 ; S. Hashimoto, K. Kano, Bull. Chem. Soc. Jap., 45, 549 (1972).

11) a) C. Kaneko, S. Yamada, I. Yokoe, N. Hata, Y. Ubukata, Tetrahedron Lett., 1966, 4729.

b) C. Kaneko, S. Yamada, I. Yokoe, ibid., 1967, 775.

c) C. Kannko, S. Yamada, I. Yokoe, Chem. Pharm. Bull. (Tokyo), 15, 356(1967).

12) N. Hata, E. Okutsu, I. Tanaka, Bull. Chem. Soc. Jap., 41, 1769 (1968).

13）椅本静信, 加納航治, 高田郁尖, 同志社大学理工学研究報 告, $12,214(1972)$.
しかし４ーニトロピリジン 1-オキシドの光反応を酸素中で行な らと, ニトロベンゼン類の場合とは異なり，ニトロ化合物の三重 項状熊が消光されるといら現象性観察されず，還元生成物とは違 った化台物，すなわち 4ーヒドロキシピリジン 1-オキシドが最終

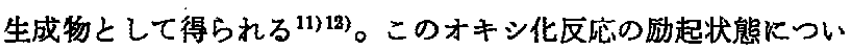
ては，現在のところ明らかにはされていない。

一方, 著者らはさきの論文で，4-ニトロピリジン（以下 4-NP と略記する）が IPA のような強い水素供与体中で光䇾元されな いが, IPA-塩酸（以下 $\mathrm{HCl}$ と略記する）溶液中では，窒素雾围 気下に光還元され，0.93 といら高い量子取率で 4-ヒドロキシル アミノピリジン（以下 4-HAP と略記する）を与えることにつき 報告した

この論文では，4-NP の HCl-IPA 溶液の光反応を，酸素雾囲 気下に行なった場合，窒素下とは異なった反応が進行することに ついて報告する。

\section{2 結果}

\section{1 光反応生成物におよばす 4-NP 初灌度の影響}

$2 \times 10^{-3} \mathrm{~mol} / l 4-\mathrm{NP}$ の $0.4 \mathrm{vol} \%$ 濃 $\mathrm{HCl}-\mathrm{IPA}$ 溶液K, 酸素 雾囲気下，130 W 高圧水銀灯 (>300 $\mathrm{nm})$ を室温で内部照射し たときのUV スペクトル経時変化を図1に示した。4-NP は， HCl-IPA 溶液中， 223 拉よび $280 \mathrm{~nm}$ に最大吸収波長（以下 $\lambda_{\max }$ と略記する）を有するが，光照射とともにこの吸収は次第 消失し，かわって $234 \mathrm{~nm}$ 飞生成物の $\lambda_{\max }$ が認められるよう になった。，この $234 \mathrm{~nm}$ の吸取は，4-とドロキシピリジン゙(以下

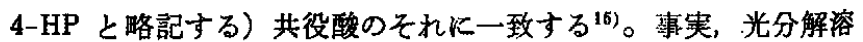
液から約 10\% の収率で 4-HP (mp 146 148 $\mathrm{C}$ ) が戦離された。

つきk, $2 \times 10^{-2} \mathrm{~mol} / \mathrm{l}$ 4-NP $94 \mathrm{vol} \%$ 濃 HCl-IPA 溶液に, 酸素雲囲気下，光照射したときのUVスペクトル経時变化を図 2 に示した。光反応生成物の吸収は，230 および $270 \mathrm{~nm}$ 付近認 められた。230 nm 付近の吸收帯は，4-HP のそれにほぼ一致し，

14) a) S. Hashimoto, K. Kano, K. Ueda, Tetrahedron Lett., 1969, 2733.

b) S. Hashimoto, K. Kano, K. Ueda, Bull. Chem. Soc. Jap., 44, 1102(1971).

15) S. F. Mason, J.Chem. Soc., 1959, 1254. 


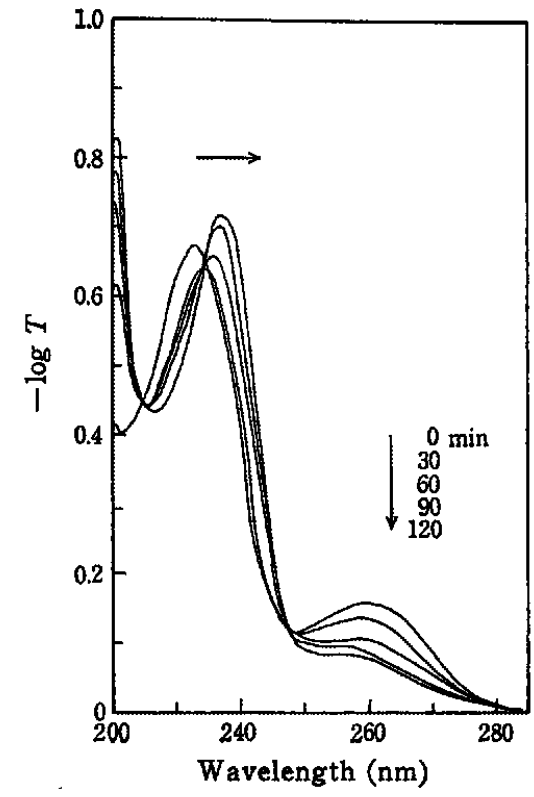

Fig. 1 The progressive spectral change of the photoreaction of 4-nitropyridine $[4-\mathrm{NP}]_{0}=2 \times 10^{-3} \mathrm{~mol} / \mathrm{l}$

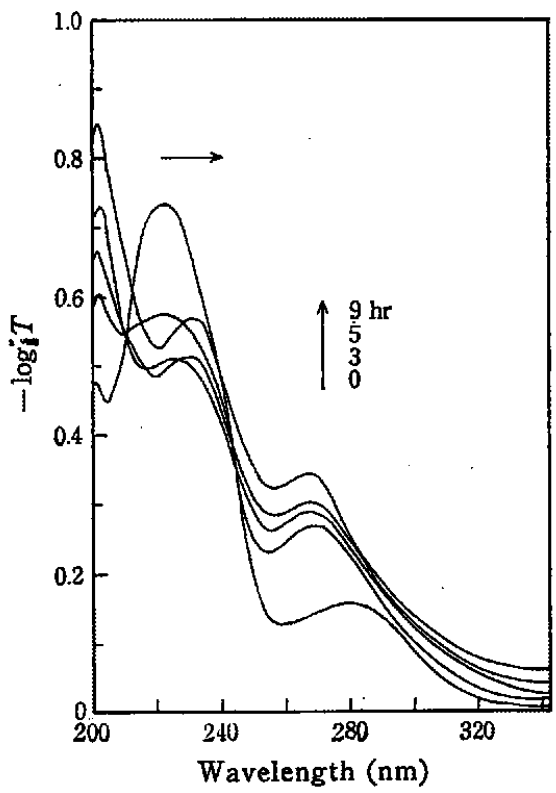

Fig. 2 The progressive spectral change of the photoreaction of 4-nitropyridine

$$
[4-\mathrm{NP}]_{0}=2 \times 10^{-2} \mathrm{~mol} / \mathrm{l}
$$

また $270 \mathrm{~nm}$ 付近の吸収帯は 4-HAP のそれ (文献値 ${ }^{14)} \lambda_{\mathrm{max}}^{\mathrm{IPA}-\mathrm{HCl}}$ $273 \mathrm{~nm}$ ) に一致した。しかし，光分解溶液を中和後，生成物の単 離を試みたところ，4-HP 扣よび 4-HAP は得られず，かわって $N$, Oージ(4-ピリジル)とドャキシルアミン (mp 183 183. $5^{\circ} \mathrm{C}$, 取

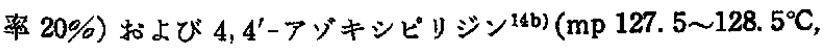

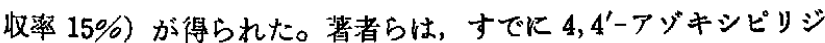
ンが，4-HAP を中性溶媒中で処理するときに得られることを見 いだしている ${ }^{14 \mathrm{~b})}$ 。のようにして光分解溶液から 4, $4^{\prime}-$ アゾキ シピリジンが単離されたことは，270 nm に $\lambda_{\max }$ を有する光反 応生成物が 4-HAP であることを示唆する。るし, $230 \mathrm{~nm}$ に $\lambda_{\max }$ を有する化合物が 4-HP であると仮定すれば， N,O-ジ(4-
ピリジル)ヒドロキシルアミンは, 4-HAP と 4-HP との縮合反庆 により生成するものであると考えられる。事実，4-HAP の塩酸 塩と 4-HP との当モルをメタノールに溶解すると，ただちに暗黒

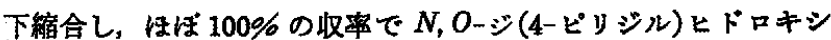
ルアミンを生成することが，UV スペクトルルより明らかとなっ た。ただし，4-HAP と 4-HP の両者を，とるに共役酸の形で用 いた場合には縮合反応は進行しなかった。

4-NP 初漫度を比較的大にした場合の光反応生成物について, つぎ検討した。 $1 \times 10^{-1} \mathrm{~mol} / \mathrm{l} 4-\mathrm{NP}$ の $10 \mathrm{vol} \%$ 漂 HCl-IPA 溶液 $100 \mathrm{ml}$ K, 酸素雾囲気下，空温て高压水銀灯を 15 時間内 部照射した。UV スペクトルの経時変化は，すでに報告した 4NP の HCl-IPA 溶液中での光逗元反応のそれ ${ }^{14)}$ と非常に類侧し ている。反応後, 溶媒を留去すると, 光䢬元生成物である 4-HAP 塩酸塩 (mp 171 $172^{\circ} \mathrm{C}$, 取率 $21.4 \%$ ) が単新され, 4-HP, $N, O$ ジ(4ーピリジル)ヒドロキシルアミンなどはまったく得られなかっ た。

\subsection{4-HP 生成における水の役割}

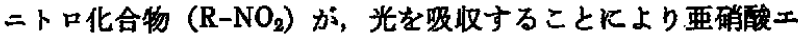
ステル体 (R-ONO) に転位する反応は数多く知られている ${ }^{16)}$ 4ニトロピリジン 1-オキシドあるいは 3,5-ジメチルー4-ニトロピ リジン 1-オキシドの対范するオキシ化合物への光化学反応では, 亚硝酸エステルが中間体として考えられている(1)。亜硝酸エステ ルあるいは，このるのが酸化されたかたらの硝酸エステル体 $\left(\mathrm{R}-\mathrm{ONO}_{2}\right)$ は，加承分解されればオキシ化合物を与兄るであろ ら。そこで要硝酸エステルあるいは硝酸エステル体が，4-NP の 光反応化おいても生成するすのかどらかを確かめる目的で，つぎ の実験を行なった。

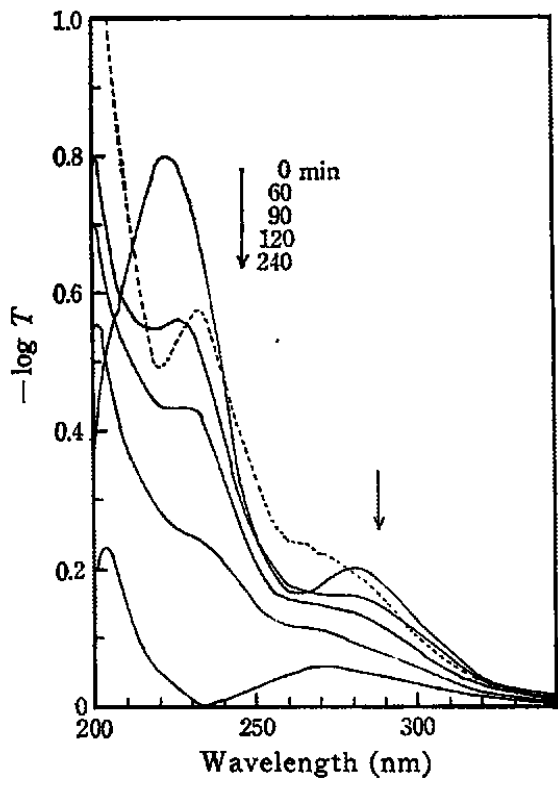

Fig. 3 The progressive spectral change of the photoreaction of 4-nitropyridine hydrochloride in absolute 2-propanol

The dotted line is the spectrum of the hydrolyzed solution of the sample drawn out after $90 \mathrm{~min}$ irradiation.

16) H. A. Morrison, "The Chemistry of the Nitro and $\mathrm{Ni}$ troso Groups", ed. by H. Feuer, Interscience Publishers, New York, N. Y. (1969) p. 117. 
$2 \times 10^{-3} \mathrm{~mol} / \mathrm{l} 4$ 4-NP 㙁酸塩の無水 IPA 溶液火, 室温, 酸素票 囲気下に高圧水銀灯を内部照射した。光反応の UVスペクトル経 時㚆化を図 3 に示す。光照射により 223 および $280 \mathrm{~nm}$ の 4-NP 共役酸に基つく吸取の強度は減少するが，234 nm の 4-HP 共役 酸の吸収は認められなかった。しかし，90 分間光照射したのち， 採取した試料に瀑 $\mathrm{HCl}$ を少量加光，IPA の沸点下で，約 1 時間 加熱したのち，この酸性溶液のUVスペクトルを測定すると，図 3 の点線で示したよらに, $234 \mathrm{~nm}$ 亿-HP K基つく吸收が観察 された。この結果法，4-HP 致 4-NP の光反応生成物ではなく， 光化学的に生成した化合物が，酸触媒下 ${ }^{17}$ 亿加水分解（暗反応） され，4-HP を与えるののであることを示唆する。4-HP の生成 前駆体としては，4-ニトロピリジン 1-オキシドの光反応との類 似性から推察し，4-NP の光転位物である要硝酸エステルするい はこのすのが酸素酸化されて生ずる硝酸エステル体を考えるのが 一応妥当であろ5。

\subsection{4-HP 生成における酭来の役割 1,3-ヘンンタジエンの影}

4-NP の 4-HP への光反応に括ける酸秦の役割扔よび光反応励 起種を明らかにする目的で，1,3-ペンタジエンを用いた三重項消 光実験を行なった。

$1 \times 10^{-4} \mathrm{~mol} / \mathrm{l} 4-\mathrm{NP}$ の $0.33 \mathrm{vol} \%$ 濃 HCI-IPA 溶液に, 4 -NP に対し 20 倍モルの 1, 3-ペンタジエンを加え，窒素等囲気下，室 温で高圧水銀灯を内部照射した。光反応の挙動は, UV スペクト ルの経時変化を測定することにより㰖察した。4-HP の生成の有 無は，1,3-ペンタジンシの強い吸收帯が，250 nm より短波長部 に存在する (4-HP の HCl-IPA 溶液中での $\lambda_{\max }$ は $\left.234 \mathrm{~nm}\right)$ た め確誌することができなかったが, 光照射後、35 分では明らかに $70 \%$ 以上の收率で，4-HAP 共役酸认基づく吸收带 $\left(\lambda_{\max } 273\right.$ nm) が認められた ${ }^{18)}$ 。すし酸妻が 4-NP の 4-HP への光反応 で，三重項消光郕としてのみ作用するるのであれ代，登素繁围気 下飞，多量の三重項消光剤を用いて行なった本光反応飞执いて， 4-HP が生成し，4-HAP の生成は㧕制されるはずである。しか るに，4-HAP への光遑元反応が優先的に進行したといらこの結 果は，4-HP を生成する反応机いて，酸素が単なる三重項消光 剂としてのみ作用するるのでないことを示唆するものであるら。 一方, 著者らはすでK， 4-NP の 4-HAP への光還元反応が 4-NP の三重項状態から進行し, その還元量子収率は 0.93 であると報 告した ${ }^{14 b)}$ 。この量子収率の值は, 4-NP の HCl-IPA 溶夜中での 系間交差收率が注活 1.0 であり，4-NP，の励起一重項は 100\% 近い収率でその三重項状熊に交差することを示すのである。以 上のことから，4-NP の HCl-IPA 溶液飞光照射して 4-HP を生 ずる反応は，4-NP の三重項状態より進行し，4-HP の生成過程 そおいて, 酸素に三重項消光剂以外の作用が存在するものと推察 される。

\section{3 考寀}

4-NP HCI-IPA 溶液の, 酸素察囲気下の光反応生成物は, 4-NP

17）光分解溶液に水を加えて加熱してて，4-HP 岋生成しなか った.

18） 4-NP の程酸酸性 IPA 中比和ける 4-HAP への光透元反 応は，1３ー3ペンタシェンKより䫒著に消光されないことが 知られてい、る
初濃度により影響され，低濃度 $\left(2 \times 10^{-3} \mathrm{~mol} / l\right)$ の揚合には 4-HP が, 一方, 高灙度 $\left(1 \times 10^{-1} \mathrm{~mol} / l\right)$ の場合飞は 4-HAP が生成し た。また中程度の 4 -NP 初濃度 $\left(2 \times 10^{-2} \mathrm{~mol} / l\right)$ の場合飞は， 4-HP と 4-HAP との両者が生成し，この三つの化合物は，暗照 下に縮合することにより，新化合物である $N, O$-ジ(4-ピリジル) ヒドロキシルアミンを与えた。

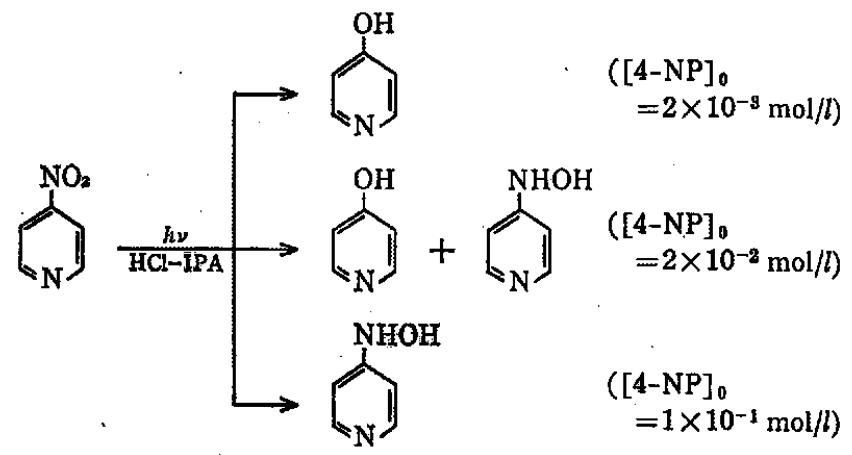

ただし，[4-NP]。は 4-NP の初濃度.

著者らは, すでに 4-NP の HCl-IPA 溶液に，窒素雾囲気下光 照射すると，4-NP 共役酸の最低三重項状熊加水菜引き抜き反 沁が進行し，4-HAP が生成すると報告した14)。窒慗雾囲気下の 光反応を今回追試して て，4-NP の初湍度 $\left(1 \times 10^{-4} \sim 1 \times 10^{-1}\right.$ $\mathrm{mol} / l)$ のいかんKかかわらず，その光反応生成物生いずれる4HAP のみであった。しかるに，4-NP 初濃度が比較的小さな場 合 $\left(2 \times 10^{-3} \mathrm{~mol} / l\right)$, 酸素票囲気下で光照射すると，光還元反応 と同じ㥐起種（4-NP 共役酸の最低三重項）を経て，4-HP への オキシ化反応が進行した。現在のところこの特異な濃度効果を説 明し得る実験結果は得られていない。

一方，4-NP 共役酸を無水 IPA 中 (4-NP 共役酸初濃度虫 $\left.2 \times 10^{-3} \mathrm{~mol} / l\right)$, 酸素雾围気下に光分解した場合，4-HP 恃生成世 ず，この光分解溶液に $\mathrm{HCl}$ 水溶液を加えて加熱することにより はじめて 4-HP が生成した。この結果から，著者らは 4-NP 共 役酸の酸素雾囲気下での光反地生成物として，4-NP 共役酸の轱 位生成物である亜硝酸エステル[1]拉よび〔1]が酸化されて 生ずる硝酸エステル体 [2]を考之た。[2]は加水分解されると 4-HP を与えるであろう ${ }^{19 \%}$ 。<smiles></smiles>

(1)

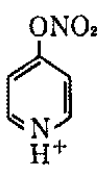

(2)
また，4-NP 初濃度が中程度の場合 $\left(2 \times 10^{-2} \mathrm{~mol} / l\right)$ Kは，4HAP と 4-HP が同時に生成し, この両者が暗黑下, 処理過程中 飞縮合して，新化合物である $N, O$-ジ(4-ピリジル)ヒドロキシル アミンが最終的に得られた。-NHO-結合の末端に同一の染香環が 直接導入されたヒドロキシルアミン類は, 現在のところ, この化 合物を除いて知られていない。一般に，ヒドロキシルアミン類と 酸クロリドとの反応で， $N$-アシル化反応が進行する場合には，七 ドロキシルアミノ基の窒素が親核中心 (nucleophilic center) $と$

19）[1] $\rightarrow[2] \rightarrow オ \neq シ$ 化合物の反応過程飞ついては文献 11) を参照. 


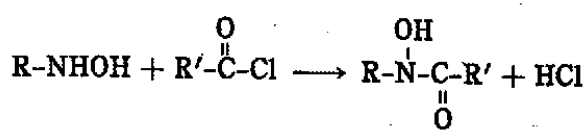

なる。しかし，立体障害あるいは電子吸引性の㯰換基の影敏を受 ける場合には、ヒドロキシルアミノ基の酸素が親核中心となる20)。

$$
\begin{aligned}
& \left(\mathrm{C}_{6} \mathrm{H}_{\mathrm{b}}\right)_{3}-\mathrm{C}-\mathrm{NHOH}+\mathrm{R}^{\prime} \mathrm{COCl} \\
& \longrightarrow\left(\mathrm{C}_{6} \mathrm{H}_{6}\right)_{9}-\mathrm{C}-\mathrm{NH}-\mathrm{O}-\mathrm{O}-\mathrm{C}-\mathrm{R}^{\prime}+\mathrm{HCl}
\end{aligned}
$$

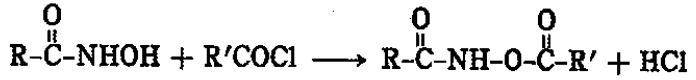

4-HAP と 4-HP との維合は, この両者がともに遊崔の婸合およ びともに共役酸を形成している場合に性進行せず，4-HAP のみ が共役酸の場合飞, 遊離の 4-HP と暗黒下注湾定量的飞縮合し, $N, O$-ジ(4-ピソジル)ヒドロキシルアミンを与えた。複素環空素 は，元来電子吸引性であるが，ピリジン環の榁素がブロトン化さ れると，その電子昨引性性堌大する。この場合，ブロトン化椱素 環窒素の強い電子吸引性のためK，ヒドロキシルアミノ基の酸素 が親核中心になると予想され，溶媒中々ト形で存在する 4-HP (4-ピリドン) の攻撃をらけるるのと考えられる。

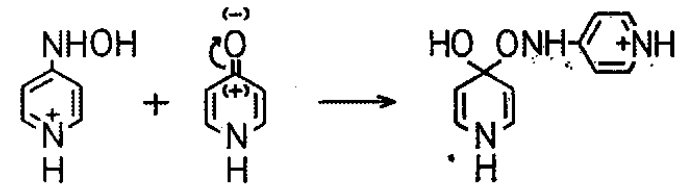<smiles>Cc1cc2cc(c1NCc1ccc[nH]1)O2</smiles>

\section{4 実 験}

\section{1 試 蒋}

4-NP21) 打よび 4-HP23)は，文献記载の方法炕より合成したもの を使用した。IPA は市股品をさらに蒸留して用いた。1,3ーペンタ ジェンは, 市眅品をさらに蒸留し， bp $42 \sim 44.7^{\circ} \mathrm{C}$ の留分を使用 した。

\section{2 置}

光反応怯，すぺて大科工業社製 $130 \mathrm{~W}$ 高圧水鍟灯 $(>300 \mathrm{~nm})$ を用いて行なった。UVスペクトルの測定は，日立製作所製 124 型自記分光光度計を使用した。

4.3 Hashimoto ら ${ }^{14)}$ の方法による 4-HAP 盐酸塭の合成

4-HAP 塩酸塩の標準物筫は，Hashimoto ら 成し，単離した。

$1 \times 10^{-2} \mathrm{~mol} / l 4$ 4-NP の $2 \mathrm{vol} \%$ 濃 HCl-IAP 溶液 $1 l$ を反応】 ラスコに入れ，系内を脱気，空素置換したのち，室温下， $130 \mathrm{~W}$ 滈生水銀灯を内部照射した。反応後，光分解溶液を減压下で約

20) P. A.S. Smith, "The Chemistry of Open-Chain Organic Nitrogen Compounds, Vol. 2", W. A. Benjamin Inc., New York, N. Y. (1966)p. 10.

21) E. Ochiai, J. Org. Chem., 18, 534(1953).

22) E. Hayashi, H. Yamada, K. Shimizu, Chem. Pharm. Bull. (Tokyo), 7, 142(1959).

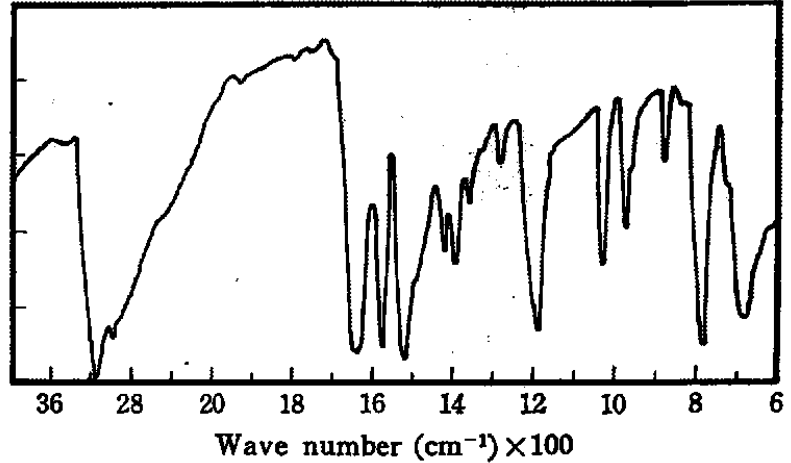

Fig. 4 IR spectrum of 4-hydroxylaminopyridine hydrochloride $(\mathrm{KBr})$

$10 \mathrm{~m} l$ まで濃縮し，析出結晶を口過した。口夜には少量のアセト ンを涯加し，結晶を析出させ，これを㓏した。两方の結晶をあ わせ, 少量のIPA およびアセトンで洗浄し，4-HAP 塩酸塩の淡

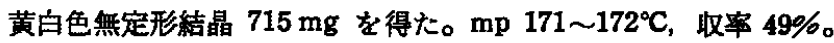
分析値 C $41.15 \%$, H $4.56 \%$, N $18.85 \%$

$\mathrm{C}_{6} \mathrm{H}_{7} \mathrm{~N}_{2} \mathrm{OCl}$ としての

計算值 C $40.96 \% ， \mathrm{H} 4.78 \%$ ，N $19.11 \%$

4-HAP 塩酸塩の IR スペクトルを図4 亿示した。

\section{4 光反応生成物}

$2 \times 10^{-8} \mathrm{~mol} / l$ 4-NP の $0.5 \mathrm{vol} \%$ 澧 HCl-IPA 溶液 $2 l \mathrm{~K}$, 酸莱票团気中，公温で $130 \mathrm{~W}$ 高圧水銀灯を 2 時間内部照射した。 光分解溶液から溶媒の約 $2 / 3$ 容量を減任留去したのち，残留物を 炭酸ナトリウムで中和した。得られた溶液からさらに溶媒を留去 し，乾固した。残留物をアセトンにて抽出（Soxhlet 抽出器を使 用）し、アセトン留去後、得られた無色結晶をアセトンから再結

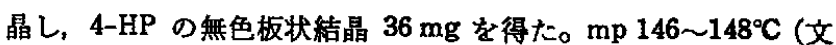
献値 ${ }^{22)} \mathrm{mp} 148 \sim 149^{\circ} \mathrm{C}$ ), 収率 $10 \%$ 。

$2 \times 10^{-2} \mathrm{~mol} / l \mathrm{l}$ 4-NP の $4 \mathrm{vol} \%$ 湦 HCl-IPA 溶液 $2 l \mathrm{k}$, 酸 亲雾团気中，室温で $130 \mathrm{~W}$ 高压水銀灯を 9 時間内部照射した。 光分解溶液から IPA の約 $1 / 2$ 容量を減压下に留去したのち，残 液を炭酸ナトリウム水溶液で中和した。この溶液から，さらに IPA を減圧下K留去し，約 $400 \mathrm{ml}$ の残夜を得た。残液を冷却 後，析出結晶を口過，残留物をメタノールから再結晶し， $N, O$ ジ(4-ピリジル)ヒドロキシルアミンの淡黄色無定形結晶 $0.74 \mathrm{~g}$

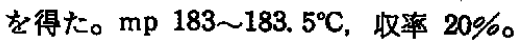

分析値 C $64.03 \%$, H $4.62 \%$ ，N $22.45 \% ，$ O $8.90 \%$ $\mathrm{C}_{10} \mathrm{H}_{9} \mathrm{~N}_{8} \mathrm{O}$ としての

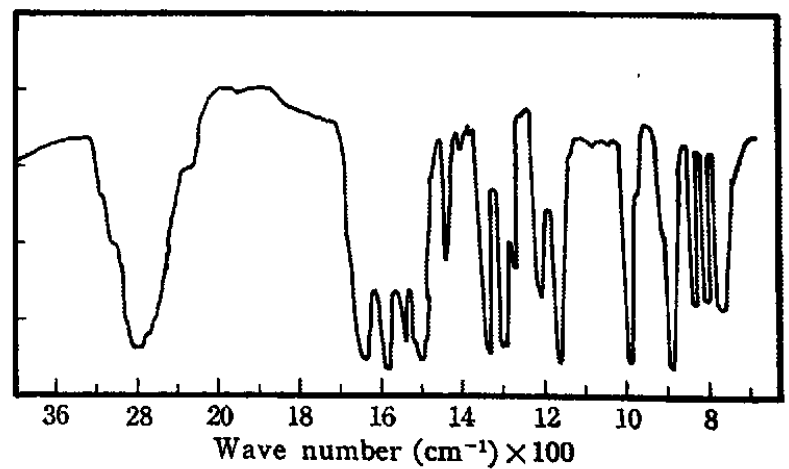

Fig. 5 IR spectum of $N, O$-di(4-pyridyl) hydroxylamine $(\mathrm{KBr})$ 
副算值 C $64.16 \%$ ，H 4.84\%，N $22.45 \% ， 08.55 \%$ 一方，口夜は減压下漧固し，残留物をアセトンで抽出（Soxhlet 抽出器使用) し，アセトン留去後，得られた淡登色結晶を水 から再結晶し，4，4'-アジキシビリジンの無色板状結晶 $0.60 \mathrm{~g}$ を 得た。mp 127.5 128. $5^{\circ} \mathrm{C}$ (文献值 ${ }^{14 b}$ ) $\mathrm{mp} 125 \sim 126.5^{\circ} \mathrm{C}$ ), 取率 $15 \%$ 。

新化合物である $N, O$-ジ(4-ピリジル)ヒドロキシルアミンは， つぎのよらな分析結果から確認した。筫量スペクトルから，親ピ 一ク $\left(\mathrm{M}^{+}\right)$は m/e $187 k,{ }^{+} \mathrm{O}-\mathrm{C}_{6} \mathrm{H}_{4} \mathrm{~N}$ に基つくピークが $m / e$ 94 飞，また $+\mathrm{HN}-\mathrm{C}_{6} \mathrm{H}_{4} \mathrm{~N}$ 飞基づくピークが m/e 93 汇観察され

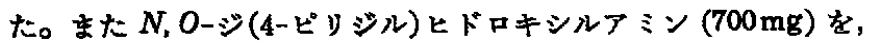

$T_{1}$-Raney ニッケルを用い接触還元した結果，77.0\% および 82. 7\% の収率で 4-アミノピリジン (mp 158.5 159. $\left.5^{\circ} \mathrm{C}\right)$ およ び 4-HP (mp 147 149 $\mathrm{C}$ ) がそれぞれ単離された。 $\mathrm{N} ; 0$ Oジ(4ピソジル)ヒドロキシルア・ミンのIR スベクトルを因5に示した。 $1 \times 10^{-1} \mathrm{~mol} / \mathrm{l} 4$-NP の $10 \mathrm{vol} \%$ 濃 $\mathrm{HCl}-\mathrm{IPA}$ 溶液 $100 \mathrm{ml} \mathrm{k}$, 酸素罢囲気中，室温で $130 \mathrm{~W}$ 高圧水銀灯を 15 時間内部照射し た。光分解溶液を減圧下飞約 $5 \mathrm{ml}$ まで灌縮した。この残液に少 量のアセトンを添加し，析出結晶をロ過，アセトンで洗消， 4-HAP 塩酸塩の無色針状結晶 $0.313 \mathrm{~g}$ を得た。 $\mathrm{mp} 171 \sim 172^{\circ} \mathrm{C}$, 收率 $21.4 \%$ 。

(1971 年 11 月，光化学討論会発表）

\section{The Photochemical Reaction of 4-Nitropyridine in the Hydrochloric Acid- 2-Propanol Solutions under the Atmosphere of Oxygen \\ Shizunobu Hashimoto, Koji Kano and Ikvo Takada \\ Department of Applied Chemistry, Doshisha University; Kamikyo-ku, Kyoto-shi, Japan}

The photochemical reaction of 4-nitropyridine in the hydrochloric acid-2-propanol solutions has been investigated under the atmosphere of oxygen. Photolysis of the $2 \times 10^{-3}, 2 \times 10^{-2}$, and $1 \times 10^{-1} \mathrm{~mol} / l$ solutions of 4-nitropyridine gave 4-hydroxypyridine, $N, O$-di(4-pyridyl)hydroxylamine, and 4-hydroxylaminopyridine, respectively. By means of UV spectroscopy, it was found that $\mathrm{N}, \mathrm{O}$-di(4-pyridyl)hydroxylamine was formed in the dark by the condensation reaction of 4-hydroxylaminopyridine hydrochloride with 4-hydroxylaminopyridine, both of which were formed photochemically. The result of the quenching study and of the value of the intersystem crossing coefficiency of 4-nitropyridine hydrochloride suggested that the photochemical reaction which produced 4-hydroxypyridine proceeded via the triplet state of 4-nitropyridine hydrochloride. The nitrite and nitrate produced by the photolysis of 4-nitropyridine were assumed as the intermediates of the 4-hydroxypyridine formation. 